\title{
GLOSA DO WYROKU SĄDU NAJWYŻSZEGO Z 4 GRUDNIA 2013 R., II CSK 161/13
}

\section{COMMENT ON JUDGEMENT OF THE SUPREME COURT OF 4 DECEMBER 2013, II CSK161/13}

Słowa kluczowe

Prawo ochrony środowiska; odszkodowania; przedawnienie roszczeń.

\section{Keywords}

Environmental law; civil liability; barred claims.

„1. Jeśli art. 129 ust. 4 u.p.o.ś. ustanawia dwuletni termin do wystąpienia $\mathrm{z}$ roszczeniem, rozumianym jako zgłoszenie roszczenia zobowiązanemu, to jego znacze-

Doktor nauk prawnych, adiunkt w Katedrze Prawa Ochrony Środowiska, Wydział Prawa i Administracji, Uniwersytet Mikołaja Kopernika w Toruniu. 
nie wyczerpuje się z chwilą dokonania takiego zgłoszenia. O przerwie biegu terminu można mówić wówczas, kiedy czynność ograniczona tym terminem nie została wykonana, lecz przed upływem terminu strony podjęły inne działania wskazujące na wolę dobrowolnego zrealizowania obowiązku, dla którego istotne znaczenie miała terminowa czynność. Jeżeli jednak w terminie wykonano czynność docelową, to czynność ta osiąga skutek, kończąc bieg terminu.

2. Roszczenie przewidziane w art. 129 ust. 2 u.p.o.ś. przedawnia się $\mathrm{w}$ terminie ogólnym $\mathrm{z}$ art. 118 k.c. Termin ten biegnie od chwili powstania roszczenia - to znaczy od dnia wprowadzenia ograniczeń korzystania z nieruchomości w drodze ustanowienia obszaru ograniczonego użytkowania, od tego momentu bowiem roszczenie jest wymagalne i może być dochodzone od zobowiązanego".

1. Istotę zagadnienia prawnego poddanego rozstrzygnięciu Sądu Najwyższego stanowi charakter prawny, ustanowionego w art. 129 ust. 4 ustawy Prawo ochrony środowiska ${ }^{1}$, terminu dochodzenia roszczeń odszkodowawczych z tytułu ograniczenia sposobu korzystania z nieruchomości w związku z ochroną środowiska oraz ustalenie charakteru przysługujących roszczeń odszkodowawczych w kontekście ich przedawnienia.

2. Orzeczenie Sądu Najwyższego zapadło w następującym stanie faktycznym: powódka od 1983 r. jest właścicielką nieruchomości zabudowanej domem jednorodzinnym, znajdującej się w odległości ok. 1,5 km od pasa startowego lotniska wojskowego. Rozporządzeniem nr 82/03 Wojewody (...) z 17 grudnia 2003 r. utworzony został obszar ograniczonego użytkowania lotniska wojskowego, a nieruchomość powódki znalazła się w strefie D tego obszaru. Po zmianie dokonanej rozporządzeniem nr 40/07 Wojewody (...) z dnia 31 grudnia 2007 r. nieruchomość powódki znalazła się w strefie I. Wprowa-

${ }^{1}$ Ustawa z dnia 27 kwietnia 2001 r. Prawo ochrony środowiska, tekst jedn. Dz.U. z 2013 r., poz. 1232 ze zm., określana dalej u.p.o.ś. 
dzenie obszaru ograniczonego użytkowania wywołało spadek i niższy przyrost cen znajdujących się na jego obszarze nieruchomości w stosunku do położonych gdzie indziej, w związku z czym wartość nieruchomości powódki uległa zmniejszeniu. Ponadto budynek powódki w momencie wprowadzenia obszaru ograniczonego użytkowania przestał spełniać wymagania prawidłowej ochrony akustycznej pomieszczeń i wymagała podjęcia robót służących wyciszeniu. Pismem z dnia 15 grudnia 2005 r. powódka wezwała pozwanego do zapłaty odszkodowania w związku z objęciem nieruchomości obszarem ograniczonego użytkowania. Wobec braku reakcji, w dniu 22 lutego 2010 r. skierowała do sądu wniosek o zawezwanie pozwanego do próby ugodowej w sprawie zapłaty odszkodowania. W związku z brakiem ugodowego załatwienia sprawy, w dniu 26 października 2010 r. powódka wniosła powództwo do Sądu. Zarówno Sąd I, jak i II instancji uznał zgłoszone powództwo za zasadne, odrzucając tym samym zarzut pozwanego dotyczący zgłoszenia roszczenia po upływie terminu wskazanego w art. 129 ust. 4 u.p.o.ś. W skardze do Sądu Najwyższego pozwany zarzucił naruszenie art. 129 ust. 4 w zw. z art. 136 ust. 1 u.p.o.ś. poprzez niezasadne przyjęcie, iż roszczenia powódki nie wygasło na skutek upływu terminu prekluzyjnego oraz naruszenie art. $442^{1} \S 1$ k.c. w zw. z art. 322 u.p.o.ś. poprzez błędne nieuwzględnienie podniesionego przez pozwanego zarzutu przedawnienia.

3. Dokonując rozstrzygnięcia $\mathrm{w}$ przedmiotowej sprawie Sąd Najwyższy przyjął, iż roszczenie z art. 129 u.p.o.ś. jest roszczeniem cywilnoprawnym o charakterze majątkowym, a odpowiedzialność podmiotu zobowiązanego nie mieści się $\mathrm{w}$ kategoriach odpowiedzialności deliktowej. W konsekwencji, przedawnienie wskazanych roszczeń następuje, zgodnie z art. 118 k.c., w terminie 10 lat od dnia w którym wystąpiło zdarzenie wywołujące szkodę, którym w przedmiotowej sprawie jest wejście w życie aktu prawa miejscowego ustanawiającego ob- 
szar ograniczonego użytkowania. W ocenie Sądu, ustanowiony w art. 129 ust. 4 u.p.o.ś., dwuletni termin do „wystąpienia z roszczeniem” jest terminem zawitym do dokonania czynności zgłoszenia roszczenia. Termin ten nie jest natomiast terminem przedawnienia roszczenia.

4. Stanowisko Sądu należy w pełni podzielić uznając je jednocześnie za konsekwentną kontynuacje przyjętej przez Sąd Najwyższy linii orzeczniczej² ${ }^{2}$.

5. Zgodnie z art. 129 ust. 1-3 u.p.o.ś., jeżeli w związku $\mathrm{z}$ ograniczeniem sposobu korzystania $\mathrm{z}$ nieruchomości korzystanie z niej lub z jej części w dotychczasowy sposób lub zgodny z dotychczasowym przeznaczeniem stało się niemożliwe lub istotnie ograniczone, właściciel nieruchomości (użytkownik wieczysty) może żądać wykupienia nieruchomości lub jej części, bądź też może żądać odszkodowania za poniesioną szkodę (roszczenie odszkodowawcze przysługuje również innej, aniżeli właściciel lub użytkownik wieczysty, osobie legitymującej się prawem rzeczowym do nieruchomości). W ust. 4 art. 129 u.p.o.ś. ustawodawca przyjął, iż ze wskazanymi powyżej roszczeniami można wystąpić w okresie 2 lat od dnia wejścia w życie rozporządzenia lub aktu prawa miejscowego powodującego ograniczenie sposobu korzystania z nieruchomości. Analiza spraw rozstrzyganych przez sądy powszechne wskazuje na daleko idące rozbieżności w sposobie interpretacji i rozumienia analizowanej normy prawnej. Szczególne wątpliwości wzbudza charakter, ustanowionego w tym przepisie, dwuletniego terminu na wystąpienie $\mathrm{z}$ roszczeniem, który to postrzegany jest bądź to jako termin przedawnienia roszczenia, bądź też jako termin zawity podjęcia określonych prawem czynności (wystąpienia z roszczeniem). Rozbieżności te zarysowały się również

2 Por. wyrok Sądu Najwyższego z 29 listopada 2012 r., II CSK 254/12, www.sn.pl, wyrok Sądu Najwyższego z 10 października 2008 r., www.sn.pl. II CSK 216/08. Odmiennie: wyrok Sądu Najwyższego z 4 lipca 2013 r., I CSK 645/12, www.sn.pl. 
w doktrynie prawa. W ocenie K. Gruszeckiego termin z art. 129 ust. 4 u.p.o.ś. jest terminem przedawnienia roszczeń odszkodowawczych ${ }^{3}$, natomiast J. Parchomiuk wskazuje, iż jest to termin zawity, którego bezskuteczny upływ powoduje utratę uprawnień ${ }^{4}$. W ocenie E. Radziszewskiego, niezachowanie tego terminu jest równoznaczne z utratą prawa do wystąpienia z roszczeniem, co wskazywało by, że Autor ten przychyla się do stanowiska o zawitym charakterze terminu, przy czym sam tezy takiej nie formułuje ${ }^{5}$.

6. W doktrynie prawa cywilnego, zarówno instytucja przedawnienia, jak i terminy zawite zaliczane są do zbiorczej kategorii tzw. dawności, przez którą rozumie się te wszystkie instytucje prawa cywilnego, które określają skutki prawne będące następstwem niewykonywania uprawnień przez czas w ustawie określony ${ }^{6}$. Istota przedawnienia łączy się $\mathrm{w}$ nierozerwalny sposób z dochodzeniem roszczeń, a jej sens sprowadza się do odmowy udzielenia ochrony prawnej osobie, której ochrona ta dotychczas przysługiwała, w związku z upływem ustawowo określonego okresu czasu7. Materialnoprawnym skutkiem przedawnienia roszczenia jest ograniczenie możliwości jego dochodzenia, rozumiane jako brak możliwości przymusowej realizacji roszczenia, które jednakże nie wygasa. Oznacza to, że wierzyciel nie jest pozbawiony potencjalnej możliwości dochodzenia roszczenia, musi jednak liczyć się z możliwością podniesienia przez dłużnika zarzutu przedawnienia i wynikających stąd skutków prawnych, w postaci oddalenia

3 K. Gruszecki, Prawo ochrony środowiska. Komentarz, Lex 2011.

4 J. Parchomiuk, Odpowiedzialność odszkodowawcza za legalne działania administracji publicznej, Warszawa 2007, s. 439.

5 E. Radziszewski, Prawo ochrony środowiska. Przepisy i komentarz, Warszawa 2003, s. 181.

6 A. Wolter, Prawo cywilne. Zarys części ogólnej, Warszawa 1977, s. 323.

7 Por. S. Wójcik, Zagadnienia etyczne przedawnienia roszczeń, [w:] Z zagadnień cywilnego prawa materialnego i procesowego, red. M. Sawczuk, Lublin 1988, s. 142 
powództwa. Roszczenie to staje się więc zobowiązaniem niezupełnym. Konsekwencją tak ukształtowanej konstrukcji prawnej jest m.in. brak możliwości uznania świadczenia spełnionego w celu zaspokojenia przedawnionego roszczenia za świadczenie nienależne, czy uznanie przez sąd zarzutu przedawnienia za nadużycie prawa $^{8}$. Wprowadzenie do porządku prawnego instytucji przedawnienia roszczeń ma na celu przede wszystkim stabilizacje stosunków prawnych, a co się z tym wiąże ograniczenie negatywnych skutków długotrwałej bierności wierzyciela w zakresie realizacji przysługujących mu praw. Wśród celów szczegółowych wskazuje się m.in. 1) ochronę prawną długotrwale istniejących stanów faktycznych, 2) przeciwdziałanie podważaniu stanu prawnego w związku z problemami dowodowymi pojawiającymi się po upływie czasu, jeśli długotrwały stan faktyczny jest zgodny ze stanem prawnym, 3) ochronę dłużnika, który przestaje liczyć się z koniecznością zaspokojenia wierzyciela,4) ochronę wymiaru sprawiedliwości przed wydawaniem przypadkowych rozstrzygnięć związanych z problemami dowodowymi i utratą wiarygodności niektórych dowodów, 5) mobilizację wierzyciela do podjęcia prawem przewidzianych działań9.

Odmiennie ukształtowana została instytucja terminu zawitego, określanego również mianem prekluzji lub terminu prekluzyjnego. Istota tego terminu sprowadza się do ustawowo określonego okresu czasu do dokonania wskazanej w przepisie czynności prawnej, z zastrzeżeniem, iż po upływie tego terminu uprawnienie do dokonania danej czynności wygasa, a ewentualnie wykonana czynności jest pozbawiona skutków prawnych. Terminy te określane są jako terminy stanowcze, gdyż

8 Por. Wyrok SN z dnia 20 października 2011 r., IV CSK 16/11, Lex 1111006, Wyrok SN z dnia 4 października 2011 r., I PK 48/11, Lex 1125243;

9 Por. J. Zrałek, Przedawnienie $w$ międzynarodowym obrocie handlowym, Zakamycze 2005, Lex online. 
jak zauważa A. Wolter, stanowią one bardziej ostre, „albo - jak to się czasem określa - bardziej intensywne czasowe ograniczenia dochodzenia lub innej realizacji praw podmiotowych" ${ }^{\prime \prime}$, co do zasady nie podlegają przywróceniu, skróceniu, czy przedłużeniu. W wyniku upływu terminu zawitego przyznane uprawnienie wygasa. Upływ terminu zawitego jest wiążący zarówno dla stron stosunku prawnego, jak i organów władzy publicznej, w tym sądów.

7. Przenosząc powyższe ustalenia na grunt analizowanej sprawy należy w pierwszej kolejności stwierdzić, iż norma prawna zawarta w art. 129 u.p.o.ś. nie określa wprost skutku niezachowania terminu określonego w ust. 4 tego przepisu w postaci wygaśnięcia roszczenia, co jest charakterystyczne dla terminów zawitych, ale również nie stanowi wprost o wprowadzeniu, odmiennego od powszechnie przyjętych w przepisach kodeksu cywilnego, terminu przedawnienia roszczenia. Na uwagę zasługuje fakt, iż o ile instytucja terminów zawitych nie została uregulowana w sposób generalny, a o każdorazowym wprowadzeniu terminu zawitego decyduje ustawodawca w normie szczegółowej, o tyle instytucja przedawnienia roszczeń majątkowych ma wyraźnie ukształtowane na poziomie kodeksowym ramy prawne. Zgodnie z przepisami kodeksu cywilnego zasadą jest, iż roszczenia majątkowe przedawniają się, a zasadniczy termin przedawnienia wynosi 10 lat, natomiast dla roszczeń okresowych oraz roszczeń związanych z prowadzeniem działalności gospodarczej - trzy lata. Oznacza to, że każdy krótszy okres przedawnienia roszczeń stanowi wyjątek od zasady sformułowanej w kodeksie cywilnym i jako taki powinien być przez ustawodawcę wyrażony w sposób oczywisty i jednoznaczny, na co wyraźnie wskazuje początkowa część przepisu art. 118 
$\mathrm{kc}^{11}$ (,jeżeli przepis szczególny nie stanowi inaczej”) ${ }^{12}$. Kolejnym argumentem uzasadniającym tezę, iż ustanowiony $\mathrm{w}$ analizowanej normie prawnej termin nie jest terminem przedawnienia roszczenia jest przyjęty przez ustawodawcę moment rozpoczęcia biegu terminu. Zgodnie z art. 129 ust. 4 u.p.o.ś. termin ten liczony jest od dnia wejścia w życie rozporządzenia lub aktu prawa miejscowego powodującego ograniczenie sposobu korzystania z nieruchomości. Przyjęcie, iż dwuletni termin jest terminem przedawnienia roszczenia, oznaczałoby iż roszczenie odszkodowawcze przedawnia się nie od momentu powstania szkody lecz od chwili zaistnienia zdarzenia, którego skutkiem jest uszczerbek majątkowy. Biorąc pod uwagę bardzo krótki termin z art.129 ust. 4 u.p.o.ś., stan ten nie byłby możliwy do pogodzenia z zasadą proporcjonalności, która to nakłada na ustawodawcę obowiązek ważenia sprzecznych z sobą interesów oraz poszukiwania rozwiązań nieprowadzących do nadmiernego ograniczenia praw jednostki. Ponadto, zgodnie $\mathrm{z}$ art. $123 \$ 1 \mathrm{kc}$ bieg przedawnienia przerywa się: 1) przez każdą czynność przed sądem lub innym organem powołanym do rozpoznawania spraw lub egzekwowania roszczeń danego rodzaju albo przed sądem polubownym, przedsięwziętą bezpośrednio w celu dochodzenia lub ustalenia albo zaspokojenia lub zabezpieczenia roszczenia, 2) przez uznanie roszczenia przez osobę, przeciwko której roszczenie przysługuje, oraz 3) przez wszczęcie mediacji. W żadnej z tych kategorii nie mieści się zgłoszenie roszczeń odszkodowawczych podmiotowi zobowiązanemu do ich realizacji. Oznacza to, że dochodzenie roszczeń przez poszkodowanego $\mathrm{w}$ trybie pozasądowym, nie prowadziłoby do przerwania

11 Ustawa z dnia 23 kwietnia 1964 r. Kodeks cywilny, tekst jedn. Dz.U. z 2014 r., poz. 121, określana dalej kc.

12 W ustawie Prawo ochrony środowiska przykładem takiej regulacji jest np. art. 196 ust. 4. Podobnie art. 188 ust. 1 ustawy z dnia 18 lipca 2001 r. Prawo wodne, tekst jedn. Dz.U. z 2012 r., poz. 145 ze zm. 
biegu terminu przedawnienia, co przy bardzo krótkim terminie dochodzenia roszczeń w znaczny sposób ograniczałoby ugodowe załatwienie przedmiotowych spraw. W końcu argumentem słusznie wyeksponowanym przez Sąd Najwyższy w orzeczeniu z 10 października 2008 r., jest kwestia odmienności trybów dochodzenia roszczeń z art. 129 u.p.o.ś. ze względu na zróżnicowane źródła ograniczeń w korzystaniu z nieruchomości oraz wynikające stąd konsekwencje dla ustalenia charakteru przyjętego $\mathrm{w}$ tym przepisie terminu ${ }^{13}$.

Odrzucenie tezy, iż wskazany w art. 129 ust. 4 u.p.o.ś termin jest terminem przedawnienia roszczeń odszkodowawczych określonych w art. 129 ust. 1-3 u.p.o.ś. pozwala przyjąć, iż rzeczony termin jest terminem zawitym do dokonania określonej czynności. Czynnością tą „jest wystąpienie z roszczeniem”. Czynność ta powinna zostać dokonana w terminie dwóch lat, od dnia wejścia w życie rozporządzenia lub aktu prawa miejscowego powodującego ograniczenie sposobu korzystania z nieruchomości.

8. Ustalenie, iż termin określony w art. 129 ust. 4 u.p.o.ś. jest terminem zawitym do „wystąpienia z roszczeniem” kluczowym staje się odniesienie do zakresu czynności, które w zamyśle ustawodawcy wyczerpują działanie objęte analizowaną normą prawną. W związku ze zmianą art. 136 ust. 1 u.p.o.ś. z 2005 r. ${ }^{14}$, zgodnie z którym sądy powszechne są właściwe w sprawach spornych dotyczących wysokości odszkodowania, szczególnego znaczenia nabrało ustalenie, czy wystąpienie z roszczeniem do podmiotu zobowiązanego, stanowi warunek sine qua non późniejszego dochodzenia roszczenia przed sądem, stanowiąc tym samy o czasowej niedopuszczalności drogi sądowej. Na takie rozumienie analizowanego przepisu może wskazywać m.in. wyrok SN z 10

13 Wyrok SN z dnia 10 października 2008 r., II CSK 216/08, www.sn.pl.

14 Ustawa z dnia 18 maja 2005 r. o zmianie ustawy - Prawo ochrony środowiska oraz niektórych innych ustaw, Dz.U. nr 113, poz. 954 ze zm. 
października 2008 r., w którym to sąd stwierdził, iż „dodanie do poprzednio obowiązującej wersji przepisu art. 136 ust. 1 ustawy Prawo ochrony środowiska określenia „W sprawach spornych" oznacza jednoznacznie, że tryb sporu sądowego dotyczącego roszczeń wymienionych $\mathrm{w}$ tym przepisie powinien zostać poprzedzony zajęciem stanowisk przez zainteresowane strony, które mogą porozumieć się pozasądowo, w zakresie obowiązku zapłaty i wysokości odszkodowania, czy też żądania wykupu nieruchomości"15.

W języku prawnym i prawniczym występuje co najmniej kilka określeń o zbliżonym lub zbieżnym z wyrażeniem „wystąpić z roszczeniem” zakresie znaczeniowym, np. zgłaszać roszczenie, dochodzić roszczeń, dochodzić roszczeń przed sądem. Wykładnia gramatyczna pozwala przyjąć, iż zwrot wystąpić z roszczeniem obejmuje swym zakresem szerokie spektrum działań podejmowanych przez uprawnionego, w celu zrealizowania roszczeń odszkodowawczych. Będą to zarówno działania związane z zakomunikowaniem swych żądań zobowiązanemu do zaspokojenia roszczeń odszkodowawczych, jak i działania ukierunkowane na sądowe dochodzenie roszczeń, np. zawezwanie do próby ugodowej przed sądem, czy wytoczenie powództwa. Nie ulega bowiem wątpliwości, iż „wystąpić z roszczeniem” jest pojęciem szerszym niż „dochodzić roszczenia przed sądem” i jako takie zawiera w sobie również te działania, które wiążą się z sądową realizacją roszczeń. A maiori ad minus „wystąpienie" z roszczeniem w rozumieniu art. 129 ust. 4 u.p.o.ś. cytowanej ustawy bez wątpienia konsumuje zawiera w sobie, wytoczenie powództwa, przez które obowiązany dowiaduje się o żądaniu powoda. Innymi słowy a fortiori ad minus z wytoczeniem powództwa bez wątpienia można i należy wręcz wiązać skutki wystąpienia z roszczeniem, gdyż wytoczenie powództwa jest szczególnym - sformalizowanym przypadkiem „wy-

Wyrok SN z dnia 10 października 2008 r., II CSK 216/08, www.sn.pl. 
stąpienia" z roszczeniem w rozumieniu art. 129 ust. 4 u.p.o.ś. cytowanej ustawy ${ }^{16}$.

9. Słusznie w glosowanym orzeczeniu Sąd Najwyższy przyjął, w konsekwencji ustalenia iż termin określony w art. 129 ust. 4 u.p.o.ś. jest terminem zawitym, że warunkiem dochowania tego terminu jest podjęcie czynności dla której został on wyznaczony. Dokonanie tej czynności kończy bieg terminu. Nie do przyjęcia jest zastosowanie $\mathrm{w}$ tym przypadku instytucji przerwania biegu terminu zawitego ${ }^{17}$, której istotą jest uchylenie negatywnych skutków upływu czasu w związku z podjęciem innych działań niż te dla których termin został wyznaczony. Skutkiem uchybienia terminu określonego w art. 129 ust. 4 u.p.o.ś. jest utrata przez poszkodowanego prawa wystąpienia z roszczeniem, a ewentualne dokonanie tej czynności po upływie terminu pozbawione będzie doniosłości prawnej. W przypadku skierowania sprawy na drogę postępowania sądowego, upływ terminu zawitego jest brany przez sąd pod uwagę z urzędu (a nie na zarzut pozwanego) i prowadzi do oddalenia powództwa.

10. Konsekwencją przyjęcia przez Sąd Najwyższy, iż wskazany w art. 129 ust. 4 u.p.o.ś. termin jest terminem zawitym dla „wystąpienia z roszczeniem” było określenie terminu przedawnienia roszczeń odszkodowawczych, których podstawę stanowi art. 129 ust. 1-3 u.p.o.ś. Dokonując rozstrzygnięcia tej kwestii Sąd Najwyższy opowiedział się za cywilnoprawnym charakterem roszczeń odszkodowawczych, wynikających z legalnych działań administracji, odrzucając jednocześnie możliwość zakwalifikowania odpowiedzialności z tytułu tzw. „szkód

16 Por. wyrok Sądu Apelacyjnego w Łodzi z 26 lutego 2013 r., I ACa 1366/12, www.orzeczenie.ms.gov.pl. oraz wyrok Sądu Najwyższego z 29 listopada 2012 r., II CSK 254/12, www.sn.pl.

17 Doktryna prawa cywilnego z dużą ostrożnością wypowiada się na temat stosowania instytucji przerwania biegu terminu, czy jego zawieszenia w odniesieniu do terminów zawitych. Por. A. Wolter, op.cit., s. 343 i n. 
legalnych" do odpowiedzialności deliktowej ${ }^{18}$. Legalne działania administracji stanowią bowiem, obok deliktu i kontraktu, odrębne źródło odpowiedzialności odszkodowawczej. Odrębność ta nie pozbawia jednakże samej odpowiedzialności, jak i roszczeń z nią związanych, charakteru cywilnoprawnego ${ }^{19}$. Przyjmując, iż roszczenia z tytułu szkód powstałych na skutek wyznaczenia przez uprawnione do tego organy obszarów ograniczonego użytkowania mają charakter cywilnoprawny i są roszczeniami majątkowymi, Sąd słusznie stwierdził, iż wobec braku odmiennego uregulowania terminu przedawnienia tych roszczeń w przepisach szczególnych, termin ten wynosi, zgodnie z art. 118 kc. - 10 lat.

\section{BIBLIOGRAFIA}

Bagińska E., Parchomiuk J., Odpowiedzialność odszkodowawcza $w$ administracji, Tom 12, System Prawa Administracyjnego, (red.)

R. Hauser, A. Wróbel, Z. Niewiadomski, Warszawa 2010.

Gruszecki K., Prawo ochrony środowiska. Komentarz, Lex 2011.

Parchomiuk J., Odpowiedzialność odszkodowawcza za legalne działania administracji publicznej, Warszawa 2007.

Radziszewski E., Prawo ochrony środowiska. Przepisy i komentarz, Warszawa 2003.

Szalewska M., Wywłaszczenie nieruchomości, Toruń 2005.

Wolter A., Prawo cywilne. Zarys części ogólnej, Warszawa 1977.

18 Szerzej na temat rozbieżności poglądów doktryny co do charakteru prawnego odpowiedzialności z tytułu szkód wyrządzonych legalnym działaniem administracji zob. J. Parchomiuk, Odpowiedzialność odszkodowawcza z legalne działania administracji publicznej, Warszawa 2007 oraz J. Parchomiuk, [w:] E. Bagińska, J. Parchomiuk, Odpowiedzialność odszkodowawcza $w$ administracji, Tom 12, System Prawa Administracyjnego, red. R. Hauser, A. Wróbel, Z. Niewiadomski, Warszawa 2010.

2/2014 i n

19 Por. M. Szalewska, Wywłaszczenie nieruchomości, Toruń 2005, s. 260 
Wójcik S., Zagadnienia etyczne przedawnienia roszczeń, [w:] Z zagadnień cywilnego prawa materialnego i procesowego, red. M. Sawczuk, Lublin 1988.

Zrałek J., Przedawnienie $w$ międzynarodowym obrocie handlowym, Zakamycze 2005, Lex online.

Kontakt e-mail:

szalew@law.umk.pl 